\section{Progress towards gene therapy}

SIR-I would like to draw attention to two points about the progress towards gene therapy that were not dealt with adequately in D. J. Weatherall's comments (Nature 331, 13; 1988) and your leading article $(331,100 ; 1988)$.

I believe that before somatic cell gene therapy is used in human subjects, it will be necessary to evaluate its safety in hundreds of laboratory animals, each of which is allowed to live until death from natural causes. This is because carcinogenesis is likely to be the principal risk of DNA insertion into somatic cells. Some risk of modification of the expression of an oncogene, using that term in its broadest sense, is undoubtedly a potential risk of this procedure. (Disruption of other types of genes in the somatic cell is not likely to have serious effects on the whole organism.) As the development of cancers is age-dependent, animals subjected to these treatments must be allowed to grow old, and as the risk is likely to be only a few percent, large numbers of animals will need to be evaluated.

Somatic cell gene therapy has much in common with tumour chemotherapy. In both situations, treatment is initially used only on patients with serious and lifethreatening disease who have much to gain and little to lose. With both treatments, the principal risk is carcinogenesis.

Most of the debate about germ-line gene therapy has focused upon ethical issues. I happen to agree that it would be unwise for the human race to accept germline gene therapy for any reason. But there is a much more compelling reason for dismissing germ-line therapy of human genetic diseases: the procedure is quite simply unnecessary. Insertion of DNA into fertilized eggs (or for that matter, into germ cells) would need to be performed in vitro. Almost all couples at risk of producing children with serious genetic deseases face a 1 in 2 (autosomal dominant) or 1 in 4 (autosomal recessive or $\mathrm{X}$-linked recessive) risk. The in vitro procedures would always involve fertilizing multiple eggs or evaluating multiple germ cells. Among these would be some that would produce affected offspring and other that would produce normal offspring. Tests to distinguish these two classes of fertilized eggs or germ cells would be needed before gene insertion could be contemplated. (Insertion of additional DNA into an already normal fertilized egg or germ cell would be quite untenable.) Gene therapy would become unnecessary because a normal fertilized egg could be chosen for implantation or a normal gamete used for fertilization.

I can see a possible future role for diagnosis of genetic deseases in eggs fertilized in vitro or in germ cells to be used for in vitro fertilization, but I cannot see any role for gene therapy of defective fertilized eggs or germ cells.

The subject of gene therapy is likely to be debated publicly for some years. It is important for scientists to realize that they must spend time explaining their plans to the general public and for members of the public (and the politicians) to realize that they must invest time and effort in understanding what the scientists are talking about if society is to make sensible decisions.

DaVID M. DANKS

The Murdoch Institute,

Royal Children's Hospital,

Parkville, Victoria 3052, Australia

\section{Arms go south}

SIR-The view of Nobel laureates that the 'conventional' wars have continued to disrupt the Southern Hemisphere while the "Northern Hemisphere has known 40 years of peace since the bombing of Hiroshima and Nagasaki" is too simplistic (Nature 331, 382; 1988). Is it not the major powers in the Northern Hemisphere that supply the conventional weapons to the feuding southern nations? If the southern nations deserve condemnation, why have the weapons factories in the United States, the Soviet Union, Britain, France and Italy been functioning at full capacity for the past 40 years or so?

It is also amusing that the Nobel laureates did not criticize France which exports 75 per cent of its massive $\$ 11$ million aerospace production.

SaCHI. SRI Kantha

Laboratory of Marine Biochemistry,

University of Tokyo,

Bunkyo-ku, Tokyo 113, Japan

\section{Funding of science}

SIR-A reason why the differences between Mayr and Weinberg on reductionism and on priorities in the funding of the sciences (Nature 330, 433; 1987 and 331, 475 ; 1988) cannot be resolved by clearing up the semantics (Mayr) or by an attempt to "express myself a little more clearly" (Weinberg) is because they are talking about two different enterprises: Mayr, with customary clarity, is talking about hierarchical or vertical reductionism (that an increased understanding at a fundamental level will not dispense with the necessity to understand the emergent properties of greater complexities in different ways), whereas Weinberg, while agreeing with that, is writing (mainly) in his response about horizontal or chronological theory-displacement -- admittedly of an elementary kind, rarely encountered, that what is true in T1 is straightforwardly subsumed in $\mathrm{T} 2$, in some kind of smooth transition. With that understanding of theory displacement, Weinberg is able to exploit the ambiguity of the word 'fundamental' to mean both 'deep' and 'elementary' and also 'fundamentally more important than other things'. The ambiguity can be seen in his lecture, in the paragraph beginning, "The case for spending large sums of money..." (Nature 330, 434; 1987).

All this could be happily left to the philosophers of science to sort out in due course, except that large sums of money are indeed at stake (for both the Superconducting Super Collider (SSC) and CERN). Whether such sums should be allocated is a social decision (as well as a scientific judgement of priority) whenever the redistribution of resources through taxation is involved. Consequently, although what Weinberg learnt about the art of congressional testimony was to keep his mouth shut, it is essential for him, and for all of us, to say a great deal more about the competition for resources than that "we don't really know with what the SSC will compete for funds". Congressional committees are one kind of forum where social considerations can be included; maybe Nature is another. In any case, the issue will not be decided by setting eliminative reductionism against theorydisplacement when both protagonists agree that the former is false and the latter inevitable. What would help the debate and the decision would be to make explicit the criteria which they (and the rest of us) actually do adopt when choices of this kind have to be made. Perhaps Weinberg will open his mouth again?

Trinity College,

JOHN W. BOWKER

Cambridge CB2 1TQ, UK

\section{Fertility symbols?}

SIR-I wish to comment on the News and Views item "Indian maize in the twelfth century BC" by C. Johannessen (Nature $332,587 ; 1988)$ - the date of the title should, of course, have been AD.

I do not understand the Western obsession that everything in Hindu temples and Hindu religious rites is a fertility symbol: rice tillers, sugar canes, coconuts and maize, all of which can be seen in the hands of various deities, were in fact simply intended to indicate the blessing for successful crops. Describing these features as anything else is just as ridiculous as describing 'Mary with baby Jesus in her arms' or sculptures of various Christian saints holding flowers as fertility symbols. Hindus never symbolized sex and fertility, but presented them as frankly as possible.

Department of Genetics,

G.R.K. SASTRY

University of Leeds,

Leeds LS2 9JT, UK 